\title{
Building and Thinking of I nnovation Mode for Piano Teaching
}

\author{
Juan Wang ${ }^{1, a}$ \\ ${ }^{1}$ Xi'an University of Arts and Science, Xi'an, Shaanxi Province, China \\ a1293966180@qq.com
}

Keywords: Piano, Piano teaching, Model construction, Thinking

\begin{abstract}
Piano teaching is a highly specialized skills. Skills and teaching mode are very easy to produce the teacher with only a high level of performance. Skills and personal experiences can teach good student misconceptions and to ignore the height of the risen from practice to theory, Now the problems are "heavy practice but light theory". In this paper, the piano teaching status quo are described, and how to build the new piano teaching model are discussed in this paper. Purpose is to improve the quality of the piano teaching, promote students interest in learning of piano.
\end{abstract}

\section{Introduction}

In China, at present the specialized music college system, established a conservatory from start children's lifelong professional, plus we attaching too much importance to technical problem, form, the piano music college professional and other professional, as the only orientation is to improve technology, generally with the pursuit of good technology, high performance, large and difficult to tune the ethos, the way more walk more narrow, and most of Europe and the United States of the affiliated high school of music colleges and universities is not set up a professional, conservatory, many great artists have come from "amateur" road [1]. But there is no denying the fact that to cultivate children of extraordinary music talent, the conservatory, the affiliated high school, undergraduate course of the form of running is very effective, as for example, gymnastics, acrobatics all competitive home make need from children started to grab, world-class instrumentalist also as demand from the selection and training of children; For piano performance art professional particularity, more need to select those in germination period and special music to exceptional intelligence, and through the special teaching form to meet their special growth it needs to develop [1]. Of course, not only from the conservatory to affiliated high school of music college undergraduate course of the road of the timber, should open mind a variety of channels, a variety of ways to select talents, officials gave birth to their own advantage will be to learn the piano professional advantages, will also be learning the piano teaching, and the theory of piano professional advantage.

The characteristics of the piano teaching in the form of individual teaching, with other teaching methods incomparable advantages, but there are also some disadvantages. Because of the piano teaching is a highly specialized skills, skills, teaching mode, it is easy to produce the teacher alone superb performance skills and personal experience can teach good student misconceptions, and ignore the height of the risen from practice to theory, "heavy practice, light theory" problems. Because individual teaching has the characteristics of flexibility, impromptu sex, on the teaching content, methods, lack of planning, too much subjective randomness [1]. These problems need to innovate teaching mode, to seek, to master scientific methods of playing and teaching methods.

\section{Construction of innovative thinking mode for piano teaching}

Update the piano teaching concept. This requires the teacher must fundamentally changing teaching idea, constantly strengthen innovation consciousness, and improve the quality of the innovation, the play to students' innovative thinking to create a good environment [1]. Optimization of piano classroom teaching is to cultivate students' innovative thinking of fundamental, piano teacher used to change over the years, the teaching habits of the first, to give up self-centeredness authority consciousness, to cultivate innovative thinking teaching implement into daily classroom teaching. Piano teacher to build democratic and harmonious classroom atmosphere, the famous 
American educator, napoleon hill once said: "confidence is the first of the soul, the chemist, when confidence fusion in mind, the subconscious mind will immediately picked up this information, turn it into an equivalent amount of spiritual power, and then transferred to the field of infinite wisdom promote successfully the materialization of ideas.", therefore, to cultivate students creative thinking is the premise of to the students to sufficient self-confidence, prompting students find self, beyond self, fully devoted to piano playing, to cultivate students calmly confident state of mind, as he played for students in one of the most relaxed state, thus get innovation power in the play, for the success of the piano teaching to lay the good foundation [2].

Train the ability of hearing. Music is the art of hearing, the piano is to describe music by stereo image, to express thoughts and feelings. Sound resolution, is feeling the music content and the most important way to music emotion, also is the important condition of that makes creative thinking form. Can guide students to accurately judge the finger after keystrokes of the piano hammer string sound is full, solid, elastic, excluding those extrusion, gone with the wind, the sound of the inelastic. In training students' finger tips at the same time, be sure to get into the habit of "hear", improve the level of students "listening". In the whole process of piano teaching, teachers should encourage the students into full play and in the understanding of music and the performance of the originality, respect and protect students' artistic personality and style of play [2]. Even if the students are in the understanding of some works or there are some errors in the process, also should not be simple to deny, can't the teacher himself to music style imposed on the student's personal preference. Famous painter qi banish once said to his disciples: "learn I born, like I die." Should teachers and students to discuss with the method of how to better the work of music charm and your own play style together, make the students from the knowledge, concepts on actively to improve their understanding of the work and perform, so as to expand students' thinking and aesthetic consciousness has the innovation, to make the students in the future play and work play their music talent and artistic personality, form their own unique style of play.

To cultivate divergent thinking ability. Stimulate the music imagination is a dominant factor to foster the creative thinking, piano art is feeling and the two aspects of coordination, the one-sided pursuit of skills training and neglect of students' innovative thinking is not scientific. Teachers should pay attention to cultivating students' good music aesthetic psychology, the rich music imagination, unique music creative thinking, so that students can accurately, deep and detailed experience emotional connotation of piano music works, make oneself of the feelings and the feelings of music works in blends, and resonance [2]. Teachers can use music in the piano classroom teaching the most attractive content in the works, trying to encourage the innovation consciousness of students, using the principle of combining theory and practice of follow the gradual, targeted for guidance and trust, expand students' thinking space, enhance the appeal of play, cultivate students creative thinking in piano learning.

\section{The construction of innovative teaching mode for piano teaching}

The innovation of the teaching content. "The piano teaching method" research and expounds the basic content of piano teaching, rules, principles and processes and methods. In terms of the piano course, "the piano teaching method" the introduction of the content will play a positive role on multiple levels. For those without the basis of piano students, "' the piano teaching method" to guide them to accurately grasp the piano course is one of the most basic, the most common knowledge content, and to guide their primary stage of learning piano. This will make them give full play to their own subjective initiative in the learning process, so as to make learning more effective, and more fun." [3] some students when they have the strong ability of piano, for these students, "the piano teaching method" on the one hand, will help them learn more comprehensive in-depth grasp piano related elements, their performance level moving towards a higher level, on the other hand "the piano teaching method" and they may be engaged in piano teaching in the future work play a theoretical guidance role for a long time.

Innovation in the form of teaching. At this stage in the form of group class teaching form is given priority to, such limits the development of some of the students, at the same time to accept the 
slow students cannot give more advice [3]. According to different stages, different levels of students timely adopt individual lessons, group classes, and a variety of forms such as large class.

Individual class: the teacher can be very meticulous and thorough observation and solve each of the students of different problems in piano, in the two level technology and art highly targeted piano teaching work, really do it according to their aptitude.

Group class: must be unified teaching materials, and basic unified learning progress. Group class we teach piano basic knowledge and method of solving more easily occur in the process of learning the piano, but also has universality, applicable to the large number and low degree of piano student.

For the teaching unit of large class: general with class [3]. Main teaching "piano teaching theory", "piano art history" and so on is given priority to with knowledge, theoretical teaching contents. Large class should make full use of all kinds of modern teaching media and teaching means, a vivid display of goes back to ancient times, wonderful piano art, to carry out multi-level and multifaceted, stereo feeling, a full range of teaching activities.

The innovation of the teaching language. Language are able to move people, completely is that it is a kind of feelings, and is a kind of thoughts and feelings [4]. Teachers only take care of students, the love for the career, with the true meaning of the heart, fully overflow in his own words, to note sentiment in the sound, moving people by feeling, to attract. Only in this includes love, care, and moving language, students' emotion to infect, strike a chord for other students, cause the resonance of the students, reduce the distance between teachers and students, attract the students [4]. This piano teaching art, different from other courses, because want to let students understand the composer's heart to pick out the tune of the thoughts and feelings at the same time, requests the teacher language vivid contagious, body language properly, guileless, combination, to reach the soul communication music language.

Teachers' classroom language quality directly affect the teaching effect, to a certain extent, determines the level of the students' language development. Therefore, the teacher in the classroom teaching, language to regulate right, pay attention to correct the students' dialect, dialect and all kinds of pet phrase [5]. Teachers' pronunciation enunciation is clear, language should be clear, should be smooth and coherence in writing, vocabulary is rich and colorful, have the newness (shown as fig.1). Teaching as much as possible the image, intuitive, lively and vivid words, to make the students easy to understand, willing to accept.
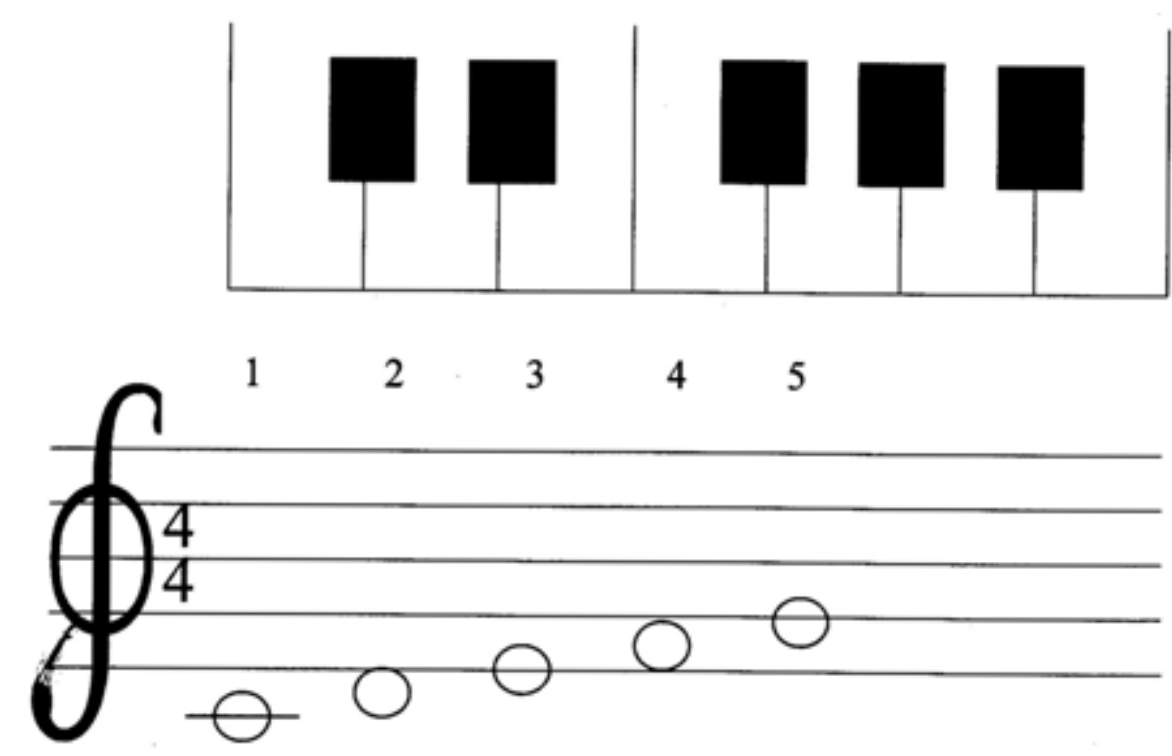

Fig. 1 Five fingers law teaching method

Language should be humorous and witty. Humorous language is a talent, but also a kind of power. In the teaching, the teacher wants to be good at the right place, the appropriate opportunity, skillfully use funny language enlightens students [2]. Such not only can make the classroom atmosphere active, also can stimulate students' interest in learning, to deepen the understanding of things, to deepen the 
understanding of music works, so that the students in the classroom atmosphere is relaxed, lively, full of laughter learned knowledge, teaching, feel the music.

Build equality between teachers and students, create a relaxed and happy learning atmosphere. Teaching subject and teaching relations are dominant, "student is the main body, the teacher is dominant. Student is the main body of teaching, students and teachers should establish a democratic, equal and harmonious relationship between teachers and students, can arouse the students' subject consciousness, independent personality development of students, stimulate students' innovation consciousness [5].

Due to differences in genetic and acquired teaching environment, students' interest in music and music potential also to have certain differences. Therefore, different students in knowledge and skills on the extent and speed are different, the feeling and understanding of music and performance also is distinguishing [5]. Teachers treat all the students can't go to the same standards, and should respect the students' personality traits and potential difference. Should be based on the students' personality characteristics, the students' participation and the development of the organic combination of different personality, according to their aptitude, let every student has the right to their own unique way of learning the piano, fully respect students' personality, hobbies, students are encouraged to make public individual character, beyond yourself, enjoy the pleasure of learning the piano.

\section{Conclusion}

The construction of innovative teaching mode provides us with talent, reform of teaching innovation space. Practice tells us that the innovation of teaching mode we realize music teaching's charm lies not in imparting knowledge and skills, but in each other between teachers and students inspire, motivate, awaken, infection and purification effect. It pay more attention to people's physical and mental health development, the cultivation of the spirit of innovation, thus to new learning style give people the desire and ability of lifelong learning.

In a word, in order to fully arouse the enthusiasm and potential of each student to learn the piano, makes them get satisfactory result in learning the piano, piano teaching mode to innovation, enable students to participate in teaching activities, foster their ability to think independently and solve problems, cultivate their good psychological quality, widen their thinking and vision, to make the students not only the piano skills, and get comprehensive development on the comprehensive quality.

\section{References}

[1] Ch. Sun, Theory of the piano teaching reform under the concept of quality teaching, Journal of social science, 2013, pp.51-54.

[2] Z.Zh. Zhang, Talking about the normal teaching in piano teaching and the cultivation of comprehensive quality talent, Journal of Liaoning teachers (social science edition), 2012, pp63-67.

[3] Y.Zhao, Cultural perspectives of contemporary Chinese piano Teaching, East China normal university, 2010, pp.21-27.

[4] D.Sun, Briefly describes the development of Chinese piano art, Journal of Changchun normal university (humanities and social science edition), 2010, pp. 43-48.

[5] Zh.Y. Liang, About piano group lesson teaching mode of study, Journal of Taiyuan city vocational and technical college, 2013, pp.141-146. 